
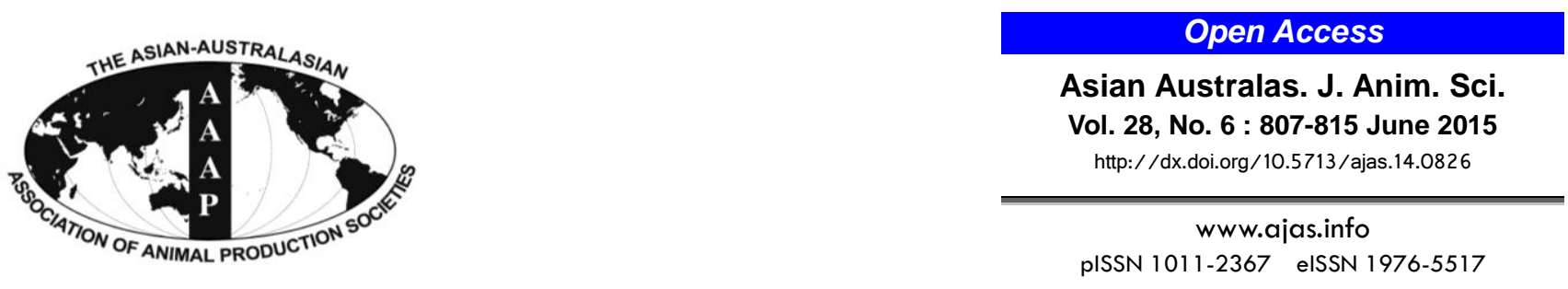

\title{
Gas Exchanges and Dehydration in Different Intensities of Conditioning in Tifton 85 Bermudagrass: Nutritional Value during Hay Storage
}

\author{
M. Pasqualotto, M. A. Neres*, V. F. Guimarães, J. Klein ${ }^{1}$, A. M. Inagaki, and C. Ducati \\ Department of Animal Science, Universidade Estadual do Oeste do Paraná, \\ Marechal Cândido Rondon, PR 85960-000, Brazil
}

\begin{abstract}
The present study aimed at evaluating the intensity of Tifton 85 conditioning using a mower conditioner with freeswinging flail fingers and storage times on dehydration curve, fungi presence, nutritional value and in vitro digestibility of Tifton 85 bermudagrass hay dry matter (DM). The dehydration curve was determined in the whole plant for ten times until the baling. The zero time corresponded to the plant before cutting, which occurred at 11:00 and the other collections were carried out at 8:00, 10:00, 14:00, and 16:00. The experimental design was randomised blocks with two intensities of conditioning (high and low) and ten sampling times, with five replications. The high and low intensities related to adjusting the deflector plate of the free iron fingers $(8$ and $18 \mathrm{~cm})$. In order to determine gas exchanges during Tifton 85 bermudagrass dehydration, there were evaluations of mature leaves, which were placed in the upper middle third of each branch before the cutting, at every hour for 4 hours. A portable gas analyser was used by an infrared IRGA (6400xt). The analysed variables were photosynthesis (A), stomatal conductance (gs), internal $\mathrm{CO}_{2}$ concentration (Ci), transpiration (T), water use efficiency (WUE), and intrinsic water use efficiency (WUEi). In the second part of this study, the nutritional value of Tifton 85 hay was evaluated, so randomised blocks were designed in a split plot through time, with two treatments placed in the following plots: high and low intensity of cutting and five different time points as subplots: cutting (additional treatment), baling and after 30, 60, and 90 days of storage. Subsequently, fungi that were in green plants as well as hay were determined and samples were collected from the grass at the cutting period, during baling, and after 30, 60, and 90 days of storage. It was observed that Tifton 85 bermudagrass dehydration occurred within 49 hours, so this was considered the best time for drying hay. Gas exchanges were more intense before cutting, although after cutting they decreased until ceasing within 4 hours. The lowest values of acid detergent insoluble nitrogen were obtained with low conditioning intensity after 30 days of storage, $64.8 \mathrm{~g} / \mathrm{kg}$ DM. The in vitro dry matter of Tifton 85 bermudagrass did not differ among the storage times or the conditioning intensities. There was no fungi present in the samples collected during the storage period up to 90 days after dehydration, with less than 30 colony forming units found on plate counting. The use of mower conditioners in different intensities of injury did not speed up the dehydration time of Tifton 85. (Key Words: Haymaking, Mower Conditioner, Stomatal Conductance, Bermudagrass)
\end{abstract}

\section{INTRODUCTION}

Tifton 85 grass plays an important role in national livestock due to its wide use as pasture and in hay production. At a smaller rate, it is used to produce silage because it shows some problems with high humidity at cutting time and the low content of soluble carbohydrates.

\footnotetext{
* Corresponding Author: M. A. Neres. Tel: +55-45-32847878, Fax: +55-45-32847878, E-mail: mabbadoneres@yahoo.com.br ${ }^{1}$ Pontifical Catholic University, Toledo, PR 85902-532, Brazil. Submitted Oct. 22, 2014; Revised Dec. 29, 2014; Accepted Jan. 30, 2015
}

Areas producing hay in Brazil have expanded enormously due to its use in dairy cows, sheep, goats and horses diets. Some producers have been qualified in hay production for trading, where there is a booming market due to its management in animal feed. The western Paraná region has glimpsed, in recent years, a great growth in hay producers because the weather during summertime allows rapid plant growth with cuts in Tifton 85 bermudagrass. Such cuts are performed every 28 days on average, combined with the wide availability of swine wastewater that fertilizes the areas and can solve an environmental problem for this region. Tifton 85 was developed by Burton et al. (1993) at

Copyright @ 2015 by Asian-Australasian Journal of Animal Sciences This is an open-access article distributed under the terms of the Creative Commons Attribution Non-Commercial License (http://creativecommons.org/licenses/by-nc/3.0/) which permits unrestricted non-commercial use, distribution, and reproduction in any medium, provided the original work is properly cited. 
the University of Georgia, in Tifton. It was derived by crossing a South African introduction (PI 290 884) with Tifton 68 and has become known for its high nutritional quality. It has low leaf drop index and is easy to regrow at low cuts, but there is a decrease in yield and quality during the winter. One of the most striking factors during the haying process is the rapid dehydration that occurs to preserve hay nutritional qualities and its phytosanitary aspects; thus, it was essential to use mowers conditioners. The conditioners machines took part of the market in the 1940s to help in plant dehydration by crushing stems, but, nowadays, there are conditioners with free-swinging flail fingers and rolls. The speed of dehydration means that fodder remains in the field for shorter periods, which minimises problems caused by rain on the dried plant. Thus, its profitable effect can be seen in the final dehydration phase, when moisture removal is slower because it occurs through the cuticle (Moser, 1995). However, mechanical injuries to the plant can cause changes in the chemical composition and digestibility of forage; therefore, it is necessary to evaluate their effects on the final composition of produced hay. Thus, this trial aimed to evaluate the conditioning intensity of a mower with free-swinging flail fingers on gas exchanges and the dehydration curve in Tifton 85 plants. The effects of a conditioner mower on fungi occurrence were also evaluated as well as the nutritional value and in vitro digestibility of Tifton 85 hay dry matter (DM) after different storage times.

\section{MATERIAL AND METHODS}

The trial was carried out on a property that produces hay in Marechal Cândido Rondon - Paraná municipality, with a total hay production area of 30 hectares. Its geographic coordinates are: latitude $24^{\circ} 33^{\prime} 40^{\prime \prime} \mathrm{S}$, longitude $54^{\circ} 04^{\prime} 12^{\prime \prime}$ $\mathrm{W}$ and altitude of $420 \mathrm{~m}$. The local climate is classified according to Köppen as $\mathrm{Cfa}$ subtropical with well distributed rains during the year and hot summers. The average temperatures of the coldest quarter vary between 17 and $18^{\circ} \mathrm{C}$, while the hottest quarter varies from $28^{\circ} \mathrm{C}$ to $29^{\circ} \mathrm{C}$ and the annual temperature is around $22^{\circ} \mathrm{C}$ to $23^{\circ} \mathrm{C}$. The total normal annual average rainfall for the region ranges from 1,600 to $1,800 \mathrm{~mm}$, with a more humidity quarter with totals ranging from 400 to $500 \mathrm{~mm}$ (IAPAR, 2006).
The values of temperature, relative humidity, dew point, solar radiation, rainfall and wind (maximum and minimum average) at the cutting and drying dates for Tifton 85 bermudagrass are shown in Table 1.

The experimental area soil was classified as Eutroferric Red Latossol (EMBRAPA, 2006) and has the following chemical characteristics: Water $\mathrm{pH}, 5.96$; $\mathrm{P}$ (Mehlich): $45.08 \mathrm{mg} / \mathrm{dm}^{3} ; \mathrm{K}$ (Mehlich): $0.72 \mathrm{cmol}_{\mathrm{c}} / \mathrm{dm}^{3} ; \mathrm{Ca}^{2+}(\mathrm{KCl} 1$ $\mathrm{mol} / \mathrm{L}): 7.93 \mathrm{cmol}_{\mathrm{c}} / \mathrm{dm}^{3} ; \mathrm{Mg}^{2+}(\mathrm{KCl} 1 \mathrm{~mol} / \mathrm{L}): 3.25$ $\mathrm{cmol}_{\mathrm{c}} / \mathrm{dm}^{3} ; \mathrm{Al}^{3+}(\mathrm{KCl} 1 \mathrm{~mol} / \mathrm{L}) \quad 0.00 \quad \mathrm{cmol}_{\mathrm{c}} / \mathrm{dm}^{3} \mathrm{H}+\mathrm{Al}$ (calcium acetate $0.5 \mathrm{~mol} / \mathrm{L}$ ): $4.14 \mathrm{cmol}_{\mathrm{c}} / \mathrm{dm}^{3}$, sum of basis: $11.90 \mathrm{cmol}_{\mathrm{c}} / \mathrm{dm}^{3}$; cation exchange capacity: 16.04 $\mathrm{cmol}_{\mathrm{c}} / \mathrm{dm}^{3} \mathrm{~V}: 74.19 \%$, organic matter (Boyocus method): $25.97 \mathrm{~g} / \mathrm{dm}^{3}$.

The swine biofertilizer analysis was carried out in an experimental area (Table 2) and nitrogen was recorded by the Kjeldahl method. For other nutrients, both nitropercloric digestion (AOAC, 2005) and reading in flame atomic absorption spectrometry method were obtained (Welz; Sperling, 1999)

The trial was carried out in an area that produces Cynodon spp. hay. Tifton 85 was introduced eight years ago to be used only for hay production and trading; this area has often received swine biofertilizer (Table 2).

The experiment was managed by a randomized design with split plots through time. There were two conditioning intensities and three storage times were placed in subplots with ten replicates. The forage cut was carried out on April 15th, 2013. The plant showed regrowth after 36 days, at 11:00 am, after dew drying. It used a mower conditioner tractor (Khun), with free iron fingers for the plants mechanical conditioning. The high and low intensities related to adjusting the deflector plate of the free iron fingers $(8$ and $18 \mathrm{~cm})$.

Dry matter production, canopy height and number of living and dead leaves per tiller were evaluated before the

Table 2. Composition of swine wastewater used as biofertilizer

\begin{tabular}{lclcc}
\hline Mineral & Content & & Mineral & Content \\
\cline { 1 - 2 } $\mathrm{N}(\mathrm{g} / \mathrm{kg})$ & 0.1 & & $\mathrm{Cu}(\mathrm{mg} / \mathrm{kg})$ & 0.07 \\
$\mathrm{~K}(\mathrm{~g} / \mathrm{kg})$ & 1.18 & & $\mathrm{Zn}(\mathrm{mg} / \mathrm{kg})$ & 0.36 \\
$\mathrm{Ca}(\mathrm{g} / \mathrm{kg})$ & 0.21 & & $\mathrm{Mn}(\mathrm{mg} / \mathrm{kg})$ & 0.1 \\
$\mathrm{Mg}(\mathrm{mg} / \mathrm{kg})$ & 0.03 & $\mathrm{Fe}(\mathrm{mg} / \mathrm{kg})$ & 0.95 \\
& & $\mathrm{P}(\mathrm{g} / \mathrm{kg})$ & 0.9 \\
\hline
\end{tabular}

Source: Agricultural and Environmental Chemistry Laboratory, Unioeste.

Table 1. Climate information during cutting and drying periods of Tifton 85

\begin{tabular}{|c|c|c|c|c|c|c|c|c|c|c|c|c|}
\hline \multirow{2}{*}{ Dates } & \multicolumn{3}{|c|}{ Temperature $\left({ }^{\circ} \mathrm{C}\right)$} & \multicolumn{3}{|c|}{ Relative humidity (\%) } & \multicolumn{3}{|c|}{ Dew point $\left({ }^{\circ} \mathrm{C}\right)$} & \multirow{2}{*}{$\begin{array}{c}\text { Radiation } \\
\left(\mathrm{kJ} / \mathrm{m}^{2}\right)\end{array}$} & \multirow{2}{*}{$\begin{array}{c}\text { Rainfall/ } \\
\text { Dew } \\
(\mathrm{mm})\end{array}$} & \multirow{2}{*}{$\begin{array}{l}\text { Wind } \\
(\mathrm{m} / \mathrm{s})\end{array}$} \\
\hline & Ave. & Max. & Min. & Ave. & Max. & Min. & Ave. & Max. & Min. & & & \\
\hline $04 / 15 / 13$ & 16.6 & 25.8 & 7.1 & 67.4 & 93.0 & 32.0 & 9.8 & 13.4 & 5.6 & $22,365.860$ & 0.0 & 1.9 \\
\hline $04 / 16 / 13$ & 17.4 & 25.1 & 9.5 & 73.0 & 94.0 & 47.0 & 12.1 & 15.1 & 8.2 & $21,452.055$ & 0.0 & 1.9 \\
\hline $04 / 17 / 13$ & 17.7 & 25.5 & 11.9 & 68.5 & 91.0 & 34.0 & 11.1 & 14.1 & 7.0 & $21,695.460$ & 0.0 & 1.0 \\
\hline
\end{tabular}

Source: Meteorological Station from the Experimental Farm, Marechal C. Rondon, PR April, 2013. 
cutting period. Thus, the following evaluations were carried out: sampling in a known area $\left(0.25 \mathrm{~m}^{2}\right)$ using a metal square, after weighing, drying in a forced air oven at $55^{\circ} \mathrm{C}$ for 72 hours and subsequent weighing, and the height of the plant canopy at five different points in each plot, with a 100 $\mathrm{cm}$ graduated ruler. A total count of leaves, green leaves and fallen leaves was carried out in ten tillers, so that the average values were of seven and two leaves, respectively, while the height value was $28.5 \mathrm{~cm}$.

After cutting and mechanical conditioning, the material remained in the field to be exposed to the sun for dehydration. The baling treatments were on April 17th, 2013 at 4:00 PM (49 hours after cutting). Rectangular bales were made for all treatments with an average weight of 10 $\mathrm{kg}$. In order to study the dehydration curve, the experiment was designed in randomized blocks with two conditioning intensities (high and low) and ten sampling times for Tifton 85. The high and low intensities related to adjusting the deflector plate of the free iron fingers $(8$ and $18 \mathrm{~cm})$. The sampling times corresponded to the following days and times of the dehydration period: First day (cut): (time 0) 11.00 o'clock, (time 1) 12.00, (time 2) 13:00, (time 3) 14.00, (time 4) 15:00, (time 5) 18.00. Second day: (time 6) 8:00 AM, (time 7) 12.00, (time 8) 16.00. Third day: (time 9) 8:00 AM, (time 10) 12.00, with five repetitions.

Samples were also taken to determine drying curves that were obtained every hour until four hours after cutting; then, the samples were carried out at 08:00, 12:00, and 16:00 every day, through the collection of samples (one from each plot) of nearly 300 grams. After sampling, the plants were packed in paper bags and dried in an oven with forced air circulation at $65^{\circ} \mathrm{C}$ for approximately 72 hours to determine DM.

In order to determine gas exchanges during dehydration, the evaluations occurred in fully expanded leaves located in the upper middle third of each branch before the cutting period, at times $0,1,2,3$, and 4 , corresponding to baseline and one to four hours after cutting. A portable photosynthesis meter (IRGA, Li 6400 model xt Inc. Lincoln, NE, USA) was used. The analyzed variables were: Photosynthesis (A, $\mu$ mol $\mathrm{CO}_{2} \mathrm{~m}^{-2} \mathrm{~s}^{-1}$ ), transpiration $(E$, $\left.\mathrm{mmol} \mathrm{H}_{2} \mathrm{O} \mathrm{m}^{-2} \mathrm{~s}^{-1}\right)$; stomatal conductance $\left(\mathrm{gs}, \mathrm{mol} \mathrm{m}^{-2} \mathrm{~s}^{-1}\right.$ ); $\mathrm{CO}_{2}$ internal concentration $\left(\mathrm{Ci}, \mu \mathrm{mol} \mathrm{CO}_{2} \mathrm{~m}^{-2} \mathrm{~s}^{-1}\right)$, water use efficiency (WUE, $\mu \mathrm{mol} \mathrm{CO}_{2} \mathrm{~m}^{-2} \mathrm{~s}^{-1} / \mathrm{mmol} \mathrm{H}_{2} \mathrm{O} \mathrm{m} \mathrm{m}^{-2}$ ), and intrinsic water use efficiency (WUEi, $\mathrm{mol} \mathrm{m} \mathrm{m}^{-1} / \mathrm{mmol}$ $\mathrm{H}_{2} \mathrm{O} \mathrm{m}^{-1} \mathrm{~s}^{-1}$ ).

The experiment was carried out in a randomized design using a split plot through time with two systems of plants conditioning at the cutting period (additional treatment) and four times to evaluate gas exchanges as subplots with ten replications. Hay was baled in rectangular bales, with an average weight of $10 \mathrm{~kg}$. Hay was stored in an enclosed brick shed, paved with a concrete floor and wooden tables which were used to prevent hay from touching it.

In stored hay, bales samples were collected at 30,60 and 90 days of storage. At the sampling time, samples were collected to determine DM and subsequent analysis of bromatological composition, in vitro dry matter digestibility and fungi occurrence.

After drying in a forced air oven at $65^{\circ} \mathrm{C}$ for almost 72 hours, the samples were ground in a one $\mathrm{mm}$ sieve Willey mill and submitted to laboratory procedures to determine crude protein (CP) contents, according to AOAC (1990), neutral detergent fiber (NDF), and acid detergent fiber (ADF), as reported by Van Soest and Robertson (1985), neutral detergent insoluble nitrogen (NDIN), acid detergent insoluble nitrogen (ADIN) according to the methodology developed by Van Soest (1965) with sulphuric acid, as described by Silva and Queiroz (2006), and hemicellulose.

The nutritional value of hay was studied based on randomized blocks in split plots through time with two treatments allocated to the plots for high and low conditioning intensity, and five times for the subplots: cut (as an additional treatment), baling and after 30, 60, and 90 days of hay storage. The soluble carbohydrate determination was obtained according to the method described by Johnson et al. (1966), with spectrophotometric reading at $480 \mathrm{~nm}$ wavelength.

The in vitro digestibility of dry matter determination was according to the technique described by Tilley and Terry (1963), adapted to the artificial rumen fluid as described by Holden (1999). A Jersey breed male (nearly $500 \mathrm{~kg}$ ), with a ruminal cannula, was used to collect bovine rumen fluid. In order to evaluate the in vitro dry matter digestibility, hay samples were weighed in amounts of $0.5 \mathrm{~g}$ sample was placed in a bags and placed in jugs containing rumen liquid and buffer solution according to the methodology described by Berchielli et al. (2001). The material remained incubated for 48 hours and after this period, HCl-pepsin $(1: 10,000)$ solution was added to the artificial fermenter at a rate of $6.68 \mathrm{~mL} / \mathrm{sample}$. Such material remained incubated for a further 24 hours. Then, the bags were removed from the rumen fermenter and washed with distilled water until the material adhering to the filter was completely removed. They were then taken to a forced ventilation oven for 8 hours at $105^{\circ} \mathrm{C}$ for drying, in order to determine dry matter.

The in vitro dry matter digestibility was calculated by the difference between the incubated amount and the residue that remained after incubation and could be calculated using the following formula:

In vitro dry matter digestibility $=100-(\mathrm{DM}$ of residual sample weight plus bag - bag weight)/initial sample weight $\times 100$ 

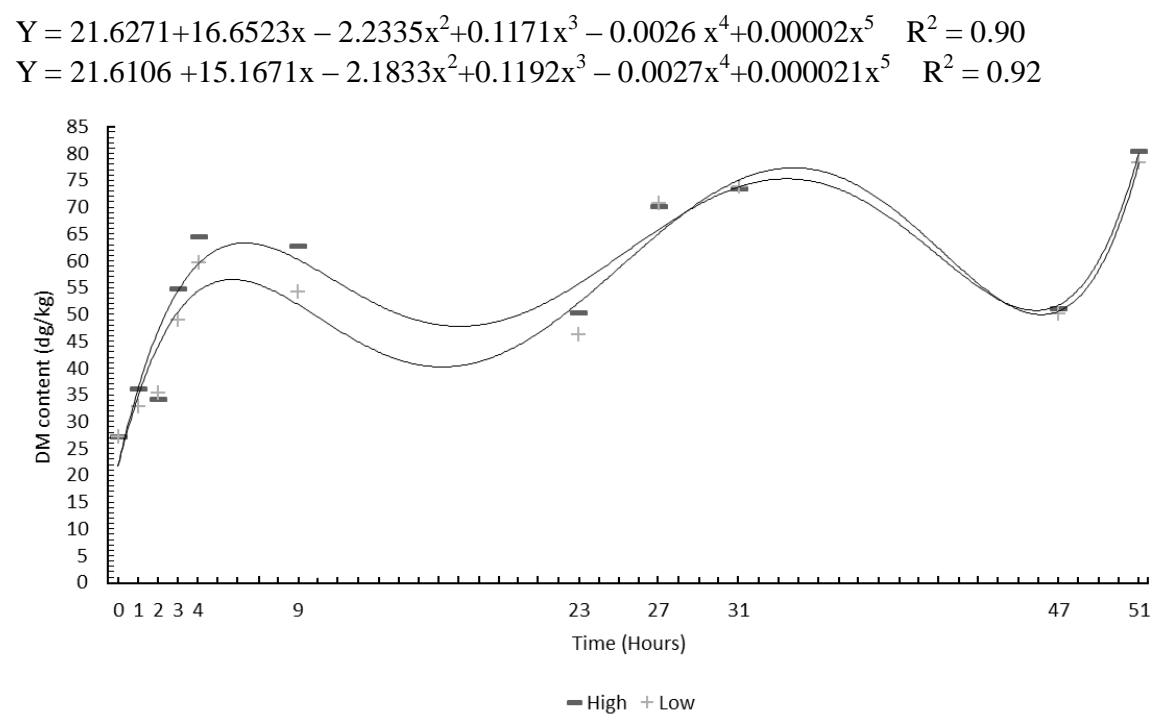

Figure 1. Dehydration curve of Tifton 85 bermudagrass under two pressure intensities of a mower conditioner.

The analyses were carried out at the Animal Nutrition Laboratory, from the Western Paraná State University, UNIOESTE. In order to evaluate fungi incidence, $100 \mathrm{~g}$ hay samples were collected before the cutting period and after 30 , 60, and 90 days of storage. Fungi were isolated by induction of mycelial growth in potato dextrose agar medium culture by induced sporulation or the direct isolation of signals (reproductive structures) of a pathogen according to the collected samples (Fernandez, 1993; Menezes and Silva-Hanlin, 1997). Dilutions ranged from $10^{1}$ to $10^{5}$; after the incubation period, the colonies were counted using Quebec colony counting. Those plates that ranged from 30 to 300 colony forming units (CFU) could be counted on the Petri dish and, in this trial, the results were considered for $10^{1}$ dilutions and expressed in log CFU g. Data were submitted to analysis of variance, and when there was some significance by the F-test, it the Tukey test was applied at $5 \%$ probability for gas exchanges and nutritional value. Dry matter contents during dehydration were analysed using regression equations and a model based on the significance of the regression coefficients and coefficients of determination.

\section{RESULTS AND DISCUSSION}

The DM in dehydration curves was adjusted by a 5th degree polynomial for both studied levels of intensity (Figure 1). It is noteworthy that the plant moisture contents were always higher in the morning due to dew.

In the first two hours of dehydration, the water loss rates were similar, but they differed in the subsequent hours with more accelerated rates due to the high conditioning level. The plants showed rehydration in the morning, although their DM contents increased throughout the day. Their DM contents showed adequate levels for storage after 49 hours.
At the baling time, the plants dry matter under highintensity conditioning provided the result $804.4 \mathrm{~g} / \mathrm{kg}$ DM, while the low intensity conditioning reached $782.3 \mathrm{~g} / \mathrm{kg}$ DM. The drying period did not exceed seven days and, according to Collins (1995), it would be the maximum time to produce the appropriate hay for animal consumption. The dehydration curve behavior was similar to that already described by Calixto Junior et al. (2007). It can be observed that the dehydration rate ranges during the drying time from 0 to 49 hours. This happens because the evening dew rehydrates the forage. However, it can be observed that the moisture acquired during the night was low and is then quickly lost after a few hours of sunshine.

Also, the intensity of tissue disruption caused by the mower conditioner on DM contents was seen, four hours after cutting $(\mathrm{p}<0.05)$, and, although there were differences among values, they were not significant (Table 3 ) at other times. Castagnara et al. (2011) recorded the highest DM contents at Tifton 85 baling with two transitions of the conditioner $(803.3 \mathrm{~g} / \mathrm{kg})$ when compared to a non-passage of the conditioner and a turn $(738.3 \mathrm{~g} / \mathrm{kg})$.

Jobim et al. (2001) obtained lower DM values when they evaluated Tifton $44(745 \mathrm{~g} / \mathrm{kg})$, Tifton $85(780.1 \mathrm{~g} / \mathrm{kg})$ and Coast-cross $(798.50 \mathrm{~g} / \mathrm{kg}$ ) after 30 hours of dehydration. Although DM contents depend on: hay forage weight to be

Table 3. Dry matter contents $(\mathrm{g} / \mathrm{kg})$ of Tifton 85 bermudagrass before cutting period and during dehydration

\begin{tabular}{lcccc}
\hline Intensity & $\begin{array}{l}\text { Before } \\
\text { cutting }\end{array}$ & $4 \mathrm{~h}$ & $21 \mathrm{~h}$ & $49 \mathrm{~h}$ \\
\hline High & $272.0^{\mathrm{aD}}$ & $646.3^{\mathrm{aB}}$ & $502.0^{\mathrm{aC}}$ & $804.0^{\mathrm{aA}}$ \\
Low & $272.0^{\mathrm{aD}}$ & $594.6^{\mathrm{aB}}$ & $462.1^{\mathrm{aC}}$ & $782.3^{\mathrm{aA}}$ \\
Average & $272.0^{\mathrm{D}}$ & $620.4^{\mathrm{B}}$ & $482.0^{\mathrm{C}}$ & $793.1^{\mathrm{A}}$ \\
\hline
\end{tabular}

Averages followed by different lowercase letters in columns and different uppercase letters in rows differ by themselves according to Tukey test at $5 \%(\mathrm{p}<0.05)$. 
Table 4. Evaluation of net assimilation, stomatal conductance, internal $\mathrm{CO}_{2}$ concentration, transpiration, water use efficiency, and intrinsic water use efficiency of Tifton 85 bermudagrass before cutting and the first four hours of dehydration

\begin{tabular}{|c|c|c|c|c|c|}
\hline Intensity & Before cutting & $1 \mathrm{~h}$ & $2 \mathrm{~h}$ & $3 \mathrm{~h}$ & $4 \mathrm{~h}$ \\
\hline \multicolumn{6}{|c|}{ Net assimilation $\left(\mathrm{A}, \mu \mathrm{mol} \mathrm{CO} \mathrm{m}^{-2} \mathrm{~s}^{-1}\right)$} \\
\hline High & $22.46^{\mathrm{a}}$ & $-2.46^{\mathrm{bA}}$ & $-2.72^{\mathrm{bA}}$ & $-2.32^{\mathrm{bA}}$ & $-2.58^{\mathrm{bA}}$ \\
\hline Low & $22.46^{\mathrm{a}}$ & $-5.29^{\mathrm{bA}}$ & $-5.71^{\mathrm{bA}}$ & $-5.53^{\mathrm{bA}}$ & $-4.99^{\mathrm{bA}}$ \\
\hline Average & 22.46 & -3.88 & -4.21 & -3.92 & -3.76 \\
\hline \multicolumn{6}{|c|}{ Stomatal conductance $\left(\mathrm{gs}, \mathrm{mol} \mathrm{m}^{-2} \mathrm{~s}^{-1}\right)$} \\
\hline High & $0.115^{\mathrm{c}}$ & $0.093^{\mathrm{cA}}$ & $0.067^{\mathrm{cA}}$ & $0.27^{\mathrm{aA}}$ & $0.22^{\mathrm{bA}}$ \\
\hline Low & $0.115^{\mathrm{a}}$ & $0.069^{\mathrm{aA}}$ & $0.067^{\mathrm{aA}}$ & $0.068^{\mathrm{aB}}$ & $0.065^{\mathrm{ab}}$ \\
\hline Average & 0.115 & 0.08 & 0.067 & 0.17 & 0.14 \\
\hline \multicolumn{6}{|c|}{ Internal $\mathrm{CO}_{2}$ concentration $\left(\mathrm{IC}, \mu \mathrm{mol} \mathrm{CO} \mathrm{CO}_{2}^{-2} \mathrm{~s}^{-1}\right.$ ) } \\
\hline High & $97.33^{\mathrm{b}}$ & $431.96^{\mathrm{aB}}$ & $438.28^{\mathrm{aB}}$ & $402.96^{\mathrm{aB}}$ & $403.39^{\mathrm{aB}}$ \\
\hline Low & $97.33^{\mathrm{b}}$ & $511.91^{\mathrm{aA}}$ & $524.56^{\mathrm{aA}}$ & $514.28^{\text {aA }}$ & $512.91^{\text {aA }}$ \\
\hline Average & 97.33 & 471.51 & 486.42 & 458.62 & 457.76 \\
\hline \multicolumn{6}{|c|}{ Transpiration (E, $\mathrm{mmol} \mathrm{H}_{2} \mathrm{O} \mathrm{m}^{-2} \mathrm{~s}^{-1}$ ) } \\
\hline High & $1.77^{\mathrm{b}}$ & $2.09^{\mathrm{bA}}$ & $1.86^{\mathrm{bA}}$ & $4.49^{\mathrm{aA}}$ & $4.63^{\mathrm{aA}}$ \\
\hline Low & $1.77^{\mathrm{a}}$ & $1.88^{\mathrm{aA}}$ & $1.95^{\mathrm{aA}}$ & $2.13^{\mathrm{aB}}$ & $1.92^{\mathrm{aB}}$ \\
\hline Average & 1.77 & 1.99 & 1.91 & 3.31 & 3.28 \\
\hline \multicolumn{6}{|c|}{ Water use efficiency (WUE, $\mu \mathrm{mol} \mathrm{CO} \mathrm{Cm}^{-2} \mathrm{~s}^{-1} / \mathrm{mmol} \mathrm{H}_{2} \mathrm{O} \mathrm{m}^{-2} \mathrm{~s}^{-1}$ ) } \\
\hline High & $12.81^{\mathrm{a}}$ & $-1.17^{\mathrm{bA}}$ & $-1.44^{\mathrm{bA}}$ & $-0.52^{\mathrm{bA}}$ & $-0.51^{\mathrm{bA}}$ \\
\hline Low & $12.81^{\mathrm{a}}$ & $-2.78^{\mathrm{bB}}$ & $-2.94^{\mathrm{bB}}$ & $-2.60^{\mathrm{bB}}$ & $-2.63^{\mathrm{bB}}$ \\
\hline Average & 12.81 & -1.98 & -2.19 & -1.56 & -1.57 \\
\hline \multicolumn{6}{|c|}{ Intrinsic water use efficiency $\left(\mathrm{WUE}_{\mathrm{i}}, \mathrm{mol} \mathrm{m}^{2} \mathrm{~s}^{-1} / \mathrm{mmol} \mathrm{H}_{2} \mathrm{O} \mathrm{m}^{-1} \mathrm{~s}^{-1}\right.$ ) } \\
\hline High & $209.45^{\mathrm{a}}$ & $-27.57^{\mathrm{bA}}$ & $-40.35^{\mathrm{bA}}$ & $-8.36^{\mathrm{bA}}$ & $-10.19^{\mathrm{bA}}$ \\
\hline Low & $209.45^{\mathrm{a}}$ & $-78.27^{\mathrm{bB}}$ & $-87.02^{\mathrm{bB}}$ & $-81.47^{\mathrm{bB}}$ & $-79.41^{\mathrm{bB}}$ \\
\hline Average & 209.45 & -52.92 & -63.68 & -44.91 & -44.80 \\
\hline
\end{tabular}

Averages followed by lowercase and uppercase on the column do not differ significantly among themselves by Tukey test at $5 \%$.

dehydrated, pile height and weather conditions. There was a drastic decrease in the rate of photosynthesis $(A)$ in the leaves of these plants after Tifton 85 plant cutting (Table 4). The negative values of photosynthesis showed high rates of plant respiration until 4 hours after cutting. On the other hand, the values for the stomatal conductance $(g s)$ did not vary drastically from the cutting time until 4 hours after it. It can be deduced that not only the plant stem but also the leaves were disrupted by the mower conditioner. This increased transpiration so that there was a difference before cutting time with the other evaluated hours.

After cutting, there is some water loss in plants, firstly by the stomata and then by the cuticles that are protected by several wax layers; hence, the stomatal pathway is important in the haymaking process due to the speed of water loss (McDonald and Clark, 1987).

In relation to the $\mathrm{Ci}$, the gas exchanges were more intense until 2 hours after cutting. This indicates that the photosynthetic apparatus is damaged by increased respiration. Such results are observed due to the negative assimilation values, thus causing $\mathrm{CO}_{2}$ accumulation in the mesophyll of leaves. It can be seen that, based on the tested conditions, four hours after cutting was sufficient to extract a large amount of water from the plant via stomatal and cuticle transpiration $(E)$, showing very low values when compared to the plants that were cut with high intensity. However, the appropriate dry matter content of the whole plant for baling $(80.40 \%)$ was reached after 49 hours of dehydration (Table 4). This also has an influence on the decreased levels of WUE as well as on the values of WUEi; this is because, within 4 hours of cutting, the lowest rate for was observed plants that were cut with high conditioning intensity.

There was some influence of cutting caused by the mower conditioner on gas exchanges variables of Tifton 85 bermudagrass (Cynodon spp.) leaves during the studied period (Table 4). In general, their highest average values were obtained before cutting, except for $\mathrm{Ci}$.

Lavezzo and Andrade (1994) evaluated the gas exchanges and considered that, in the first phase, the drying is fast and involves severe water loss, so there is a decrease in humidity that varies from almost $80 \%$ to $85 \%$ for contents that range from $65 \%$ to $60 \%$, with the main water loss occurring through transpiration. The stomatal aperture depends on leaf water status and on the evaporative demand of the atmosphere. Several observations have shown that stomatal conductance decreases due to an increase in steam deficit that occurs between the leaf and air and that the 
response is associated to the leaf transpiration rate (Schulze, 1993).

The DM contents were lower at the cutting time when compared to the other storage times (Table 5). At the cutting time, the value obtained was $272.7 \mathrm{~g} / \mathrm{kg} \mathrm{DM}$, which can be explained by the high amount of water present in the stem and leaves of the grass to be cut. There was no significant difference ( $p>0.05)$ among the intensities of the cut, although the highest values were shown at cutting time with low conditioning intensity for storage periods.

Variations in DM contents before cutting and during storage occurred due to changes in climatic conditions in such period; also, according to Raymond et al. (1978), hay can absorb and lose water. Regarding $\mathrm{CP}$, although there were no differences $(p<0.05)$ after 60 days of storage with the lowest value, $113.4 \mathrm{~g} / \mathrm{kg}$ for low conditioning intensity, the variation was low; thus, they do not interfere with the quality of stored hay. According to Reis et al. (2001), changes in $\mathrm{CP}$ concentration can be attributed to the partial loss of leaves at the storage time, whereas the highest concentrations of $\mathrm{CP}$ were found in leaves, but, at 90 days, the contents were similar.

In another study, Ames (2012) obtained different results when compared to this trial. There was an increase in $\mathrm{CP}$ content after 30 days of baling for Tifton 85 bermudagrass hay; however, Ames also observed a high occurrence of fungi in stored hay, which may have influenced such changes.

The lowest ADIN values were obtained with low conditioning intensity after 30 days of storage, $64.8 \mathrm{~g} / \mathrm{kg}$ DM (Table 5). There were differences $(\mathrm{p}<0.05)$ among the intensities of conditioning for ADIP values during hay storage period with low conditioning intensity, which presented the lowest values. The ADIN/protein is unavailable to the animal; therefore, it is not feasible that its values increase with hay storage. Castagnara et al. (2011) found similar results to this study based on ADIN results, when the authors evaluated Tifton 85 bermudagrasss hay in the winter, during periods of cutting, baling and after 30 days of storage. The NDIN contents showed no difference ( $p>0.05$ ) between results for cutting, baling and 30,60, and 90 days of storage, but the low intensity tended to increase in relation to high intensity. The NDIN averages for both high and low intensity of cut were 109.9 and $120.0 \mathrm{~g} / \mathrm{kg}$ DM, respectively.

Castagnara et al. (2011) evaluated Tifton 85 bermudagrass hay at cutting, baling and after 30 days of storage and found differences $(\mathrm{p}<0.05)$ for NDIN between the time of cutting and at other times; however, the lowest NDIN value was recorded at the cutting time and the highest was recorded 30 days after baling. The results obtained by the aforementioned authors contradict those presented in this trial, since the highest values were found at cutting time and the lowest value was at 60 days of storage (Table 5). These results contradict the statement by Turner et al. (2002), who pointed out that the nutritional value of forage changes rapidly during the first two weeks of storage, but remains relatively stable after such period thereafter.

The NDF contents (Table 6) showed no difference ( $p>0.05$ ) for both sampling time (cutting, baling and 30, 60, and 90 days of storage) and for intensity conditioning of Tifton 85. The results of NDF contents ranged from 736.4 $\mathrm{g} / \mathrm{kg} \mathrm{DM}$ at the cutting time of $760.6 \mathrm{~g} / \mathrm{kg} \mathrm{DM}$ at 90 days of storage in plants with high intensity conditioning; 740.4 $\mathrm{g} / \mathrm{kg} \mathrm{DM}$ at cutting time and $755.5 \mathrm{~g} / \mathrm{kg} \mathrm{DM}$ at 90 days of storage in plants with low intensity conditioning. These

Table 5. Contents of Dry matter (DM), crude protein (CP), acid detergent insoluble nitrogen (ADIN) and neutral detergent insoluble nitrogen (NDIN) of Tifton 85 bermudagrass under two intensities of conditioning and storage periods

\begin{tabular}{|c|c|c|c|c|c|c|}
\hline Intensity & Cut & Baling & $30 \mathrm{~d}$ & $60 \mathrm{~d}$ & $90 \mathrm{~d}$ & Average \\
\hline \multicolumn{7}{|l|}{ DM (g/kg) } \\
\hline High & $272.7^{\mathrm{b}}$ & $804.0^{\mathrm{aA}}$ & $882.6^{\mathrm{aA}}$ & $876.7^{\mathrm{aA}}$ & $887.3^{\mathrm{aA}}$ & $667.2^{\mathrm{A}}$ \\
\hline Low & $272.7^{\mathrm{b}}$ & $782.3^{\mathrm{aA}}$ & $889.2^{\mathrm{aA}}$ & $878.6^{\mathrm{aA}}$ & $888.5^{\mathrm{aA}}$ & $666.3^{\mathrm{A}}$ \\
\hline Average & 272.7 & 793.1 & 885.9 & 877.6 & 887.9 & - \\
\hline \multicolumn{7}{|l|}{$\mathrm{CP}(\mathrm{g} / \mathrm{kg})$} \\
\hline High & $126.9^{\mathrm{a}}$ & $120.1^{\mathrm{aA}}$ & $119.9^{\mathrm{aA}}$ & $126.8^{\mathrm{aA}}$ & $120.8^{\mathrm{aA}}$ & $122.9^{\mathrm{A}}$ \\
\hline Low & $126.9^{\mathrm{a}}$ & $116.6^{\mathrm{aA}}$ & $122.2^{\mathrm{aA}}$ & $113.4^{\mathrm{bA}}$ & $123.0^{\mathrm{aA}}$ & $120.4^{\mathrm{A}}$ \\
\hline Average & 126.9 & 118.3 & 121.0 & 120.1 & 121.9 & - \\
\hline \multicolumn{7}{|c|}{ ADIN (g/kg) } \\
\hline High & $86.3^{\mathrm{a}}$ & $70.1^{\mathrm{bA}}$ & $81.8^{\mathrm{aA}}$ & $87.2^{\mathrm{aA}}$ & $86.8^{\mathrm{aA}}$ & $82.4^{\mathrm{A}}$ \\
\hline Low & $86.3^{\mathrm{a}}$ & $75.9^{\mathrm{aA}}$ & $64.8^{\mathrm{bB}}$ & $71.0^{\mathrm{bB}}$ & $77.1^{\mathrm{aA}}$ & $75.0^{\mathrm{A}}$ \\
\hline Average & 86.3 & 73.0 & 73.3 & 79.1 & 81.9 & \\
\hline \multicolumn{7}{|c|}{ NDIN (g/kg) } \\
\hline High & $113.6^{\mathrm{a}}$ & $108.6^{\mathrm{aA}}$ & $109.6^{\mathrm{aA}}$ & $106.2^{\mathrm{aA}}$ & $115.5^{\mathrm{aA}}$ & $109.9^{\mathrm{B}}$ \\
\hline Low & $113.6^{\mathrm{a}}$ & $119.5^{\mathrm{aA}}$ & $119.1^{\mathrm{aA}}$ & $123.9^{\mathrm{aA}}$ & $117.4^{\mathrm{aA}}$ & $120.0^{\mathrm{A}}$ \\
\hline Average & 113.6 & 114.0 & 114.3 & 115.0 & 116.5 & - \\
\hline
\end{tabular}

Averages followed by different lowercase in rows and different uppercase letters in columns differ by Tukey test at $5 \%$ (p<0.05). 
Table 6. Contents of neutral detergent fiber (NDF), acid detergent fiber (ADF) and hemicellulose of Tifton 85 bermudagrass under two intensities of conditioning and storage periods

\begin{tabular}{|c|c|c|c|c|c|c|}
\hline Intensity & Cut & Baling & $30 \mathrm{~d}$ & $60 \mathrm{~d}$ & $90 \mathrm{~d}$ & Average \\
\hline \multicolumn{7}{|l|}{ NDF (g/kg) } \\
\hline High & $736.4^{\mathrm{a}}$ & $748.9^{\mathrm{aA}}$ & $746.4^{\mathrm{aA}}$ & $743.7^{\mathrm{aA}}$ & $760.6^{\mathrm{aA}}$ & $747.2^{\mathrm{A}}$ \\
\hline Low & $736.4^{\mathrm{a}}$ & $736.1^{\mathrm{aA}}$ & $750.7^{\mathrm{aA}}$ & $743.3^{\mathrm{aA}}$ & $755.5^{\mathrm{aA}}$ & $745.2^{\mathrm{A}}$ \\
\hline Average & 736.4 & 742.5 & 748.6 & 743.5 & 758.1 & - \\
\hline \multicolumn{7}{|l|}{$\mathrm{ADF}(\mathrm{g} / \mathrm{kg})$} \\
\hline High & $512.7^{\mathrm{b}}$ & $491.6^{\mathrm{bA}}$ & $528.9^{\mathrm{abA}}$ & $556.8^{\mathrm{abA}}$ & $580.0^{\mathrm{aA}}$ & $534.0^{\mathrm{A}}$ \\
\hline Low & $512.7^{\mathrm{b}}$ & $403.0^{\mathrm{bA}}$ & $379.4^{\mathrm{bB}}$ & $401.9^{\mathrm{bB}}$ & $523.7^{\mathrm{aA}}$ & $444.1^{\mathrm{B}}$ \\
\hline Average & 512.7 & 447.3 & 454.2 & 479.3 & 551.8 & - \\
\hline \multicolumn{7}{|c|}{ Hemicellulose $(\mathrm{g} / \mathrm{kg})$} \\
\hline High & $223.7^{\mathrm{b}}$ & $257.3^{\mathrm{aA}}$ & $217.5^{\mathrm{abA}}$ & $186.8^{\mathrm{bB}}$ & $180.5^{\mathrm{bA}}$ & $210.6^{\mathrm{B}}$ \\
\hline Low & $223.7^{\mathrm{b}}$ & $333.1^{\mathrm{aA}}$ & $371.2^{\mathrm{aA}}$ & $341.4^{\mathrm{aA}}$ & $231.8^{\mathrm{bA}}$ & $319.4^{\mathrm{A}}$ \\
\hline Average & 223.7 & 295.2 & 294.4 & 264.1 & 206.2 & - \\
\hline
\end{tabular}

Averages followed by different lowercase letters in rows and different uppercase letters in columns differ by Tukey test at $5 \%$ (p<0.05).

values are high, which may influence hay consumption.

The hemicellulose contents showed differences $(\mathrm{p}<$ 0.05 ) for the intensities of the conditioner (Table 6); however, there was no difference $(p>0.05)$ among the storage times, which may be related to NDF contents that also remained stable during the storage period.

The ADF contents showed differences $(\mathrm{p}<0.05)$ between the cutting time and the other storage times for plants with high and low intensity conditioning (Table 6). The lowest value was found at the baling time $(403.0 \mathrm{~g} / \mathrm{kg} \mathrm{DM})$ and the highest occurred after 90 days of storage $(580.0 \mathrm{~g} / \mathrm{kg} \mathrm{DM})$. Changes in $\mathrm{ADF}$ values between the cut time and the first period of storage and then the increase in their values may be associated with changes of fibrous components and must be due to dry matter losses that naturally occur with hay storage (Buckmaster et al., 1989).

The values of hemicellulose showed a significant decrease $(\mathrm{p}<0.05)$ between the cutting time and after 30,60, and 90 days of storage for plants with high intensity conditioning when compared to the baling time. Plants with low intensity conditioning showed higher values of hemicellulose at baling and during the storage period when compared to plants cut with high intensity conditioning.
Taffarel et al. (2011) evaluated Tifton 85 bermudagrass hay with 35 days of regrowth during summertime at the cutting period, baling and 30 days after baling, and obtained similar values to those recorded in this study. The highest values of hemicellulose occurred during the cutting period and then decreased with storage time.

According to Van Soest (1994), this behavior is common; therefore, hemicellulose is a heterogeneous collection of amorphous polysaccharides with a much lower degree of polymerization to cellulose and their values are decreased in stored hay partly due to cellulose expansion. The in vitro digestibility of Tifton 85 bermudagrass dry matter (Table 7) differed ( $\mathrm{p}<0.05)$ among the evaluated storage times at low intensity of conditioning and is superior at the baling period. The intensities of conditioning showed no differences $(p>0.05)$ for high and low answers at all of the evaluated times.

In this study, it was observed that IVDMD was high when compared to the values found by Ames (2012). The author analysed different ways to manage Tifton 85 bermudagrass during the winter and observed values of $466.20 \mathrm{~g} / \mathrm{kg}$ for in vitro digestibility of dry matter average at the cutting period and $376.00 \mathrm{~g} / \mathrm{kg}$ after 30 days of storage.

Table 7. In vitro digestibility and soluble carbohydrate concentration of Tifton 85 bermudagrass dry matter under two intensities of conditioning and storage periods

\begin{tabular}{|c|c|c|c|c|c|c|}
\hline Intensity & Before cutting & Baling & $30 \mathrm{~d}$ & $60 \mathrm{~d}$ & $90 \mathrm{~d}$ & Average \\
\hline \multicolumn{7}{|c|}{ In vitro digestibility of dry matter $(\mathrm{g} / \mathrm{kg})$} \\
\hline High & $651.8^{\mathrm{a}}$ & $628.9^{\mathrm{aA}}$ & $672.6^{\mathrm{aA}}$ & $666.7^{\mathrm{aA}}$ & $653.0^{\mathrm{aA}}$ & $654.6^{\mathrm{B}}$ \\
\hline Low & $651.8^{\mathrm{a}}$ & $703.1^{\mathrm{bA}}$ & $681.3^{\mathrm{aA}}$ & $699.3^{\mathrm{aA}}$ & $672.0^{\mathrm{aA}}$ & $681.5^{\mathrm{A}}$ \\
\hline Average & 651.8 & 666.0 & 677.0 & 683.0 & 662.5 & - \\
\hline \multicolumn{7}{|c|}{ Soluble carbohydrates $(\mathrm{g} / \mathrm{kg})$} \\
\hline High & $27.60^{\mathrm{a}}$ & $25.84^{\mathrm{abA}}$ & $22.41^{\mathrm{bcA}}$ & $20.79^{\mathrm{cA}}$ & $24.17^{\mathrm{abcA}}$ & $24.36^{\mathrm{A}}$ \\
\hline Low & $27.60^{\mathrm{a}}$ & $26.89^{\mathrm{abA}}$ & $20.47^{\mathrm{cA}}$ & $23.08^{\mathrm{abcA}}$ & $22.38^{\mathrm{bcA}}$ & $24.08^{\mathrm{A}}$ \\
\hline Average & 27.6 & 26.36 & 21.44 & 21.93 & 23.78 & - \\
\hline
\end{tabular}

Averages followed by different lowercase in rows and different uppercase letters in columns differ by Tukey test at $5 \%$ ( $<<0.05$ ). 
However, the period of forage growth was much higher than that observed in this study.

There was a decrease in soluble carbohydrate levels (Table 7) when compared to previous times, from 30 days of storage. Also, there were no differences $(p>0.05)$ in soluble carbohydrates among intensities of conditioning. These changes may be due to the continuation of metabolic processes in hay during the storage period (Dwain and Vallentine, 1999). Changes in hay composition during the storage time should be further studied based on the actions of microorganisms, mainly fungi and yeasts, as well as the continued metabolic processes that undergo interference of baling moisture from plants and storage conditions.

The values for soluble carbohydrate variables were lower in this study than those already found by Ribeiro et al. (2001). The authors evaluated Tifton 85 at different cutting ages and obtained an average of $40.36 \mathrm{~g} / \mathrm{kg}$ DM; however, in this trial, the average before cutting was $27.60 \mathrm{~g} / \mathrm{kg} \mathrm{DM}$. These values were considered low, but common in tropical grasses, which are naturally low in soluble carbohydrates.

Fungi presence was not observed in samples collected during the storage period up to 90 days after dehydration and the counting was less than $30 \mathrm{CFU}$ on the plate. During the baling period, the DM contents promoted favourable conditions for the proper preservation of forage material, so the onset and development of fungi were inhibited. Ames (2012) carried out a trial concerning fungi storage such as Aspergillus and Penicillium. They are usually developed when hay shows higher moisture content, which may serve as a biological indicator of the storage conditions. Scudamore and Livesey (1998) published a review concerning the occurrence of mycotoxins in silages. The authors reported that, under adverse conditions of production and storage, losses of dry matter may occur due to the presence of fungal contaminants.

\section{CONCLUSION}

Tifton 85 bermudagrass has appropriate characteristics for rapid dehydration. Tifton 85 hay stored for 90 days did not show any changes in $\mathrm{CP}$ concentration, despite the intensity of mower conditioning. According to the evaluated conditions and concerning the intensity of conditioning and storage time, Tifton 85 bermudagrass hay did not provide fungi growth.

\section{REFERENCES}

Ames, J. P. 2012. Tifton 85 Bermudagrasshay Production Systems in Winter. Master dissertation, University of West Paraná, Campus Marechal C. Rondon, Paraná, Brazil. 81 p.

Association of Official Analytical Chemists (AOAC). 1990. Official Methods of Analysis. 15th ed., Arlington, VA, USA.
1117.

Burton, G. W., R. N. Gates, and G. M. Hill. 1993. Registration of 'Tifton 85' Bermuda grass. Crop Sci. 33:644-645.

Berchielli, T. T., A. P. O. Sader, F. L. Tonani, S. F. Pazini, and P. Andrade 2001. Use the ANKOM system to determine neutral detergent fiber and acid detergent fiber with different filter bags and sample amounts. Rev. Bras. Zootec. 30:1572-1578.

Buckmaster, D. R., C. A. Rotz, and D. R. A. Mertens. 1989. Model of alfalfa hay storage. Trans. ASAE 32:30-36.

Calixto Júnior, M., C. C. Jobim, and M. W. do Canto. 2007. Dehydratation curve and chemical-bromatologic composition of stargrass (Cynodon nlemfunesis Vanderyst) hay in function of the baling process moisture content. Semina: Ciências Agrárias, Londrina, Brazil. 28:493-502.

Castagnara, D. D., J. P. Ames, M. A. Neres, P. S. R. Oliveira, F. B. Silva, E. E. Mesquita, J. R. Stangarlin, and G. Franzener. 2011. Use of conditioners in the production of Tifton 85 grass hay. R. Bras. Zootec. 40:2083-2090.

Collins, M. 1995. Hay preservation effects on yield and quality. In: Post-harvest Physiology and Preservation of Forages (Eds. K. J. Moore, D. M. Kral, and M. K. Viney). American Society of Agronomy, Madison, WI, USA. 67-89.

Dwain, R. H. and J. F. Vallentine. 1999. Harvested Forages. Academic Press, San Diego, CA, USA. 426 p.

Brazilian Research Company and Livestock. 2006. Brazilian Systems of Soil Classification, Brasília. p. 412.

Fernandez, M. R. 1993. Manual laboratory for plant pathology. Brazilian Research Company and Livestock, Passo Fundo, Brazil. p. 128.

Holden, L. A. 1999. Comparison of methods of in vitro dry matter digestibility for tem feeds. J. Dairy Sci. 82:1791-1794.

IAPAR. Climate letters of Paraná, Brazil 2006. Disponível em: http://200.201.27.14/Site/Sma/Cartas_Climaticas/Classificacao _Climaticas.htm Accessed August 3, 2013.

Jobim, C. C., L. Lombard, G. D. Gonçalves, L. Lombardi, G. D. Gonçalves, U. Cecato, G. T. Santos, and M. W. Canto. 2001. Dehydratation of Cynodon grass cultivars during haymaking. Acta Scientiarum 23:795-799.

Johnson, R. R., T. L. Balwani, and L. J. Johnson. 1966. Corn plant maturity. Effect on in vitro cellulose digestibility and soluble carbohydrate content. J. Anim. Sci. 25:617-623.

Lavezzo, W. and J. B. Andrade. 1994. Forage conservation. Hay and silage. In: Proceedings of the Brazilian Symposium on forage and pastures. Campinas, São Paulo, Brazil. 105-1066.

McDonald, A. D. and E. A. Clark. 1987. Water and quality loss during field drying of hay. Advances in Agronomy. Madison 41:107- 437.

Menezes, M. and D. M. W. Silva-Halin. 1997. Pratical guide for pathogenic fungi. Recife: UFRPE, $106 \mathrm{p}$.

Raymond, F. Shepperon, G. and R. Waltham 1978. Forage Conservation and Feeding. Farming Press, Ipswich, UK. p. 208.

Reis, R A., A. L. Moreira, and M. S. Pedreira. 2001. Thechniques for production and conservation of hay of high quality forage. In: Proceedings of the Symposium on production and use of conserved forage. Maringá, Paraná, Brazil. p 1-39.

Ribeiro, K. G., O. G. Pereira, S. C. Valadares Filho, R. Garcia, and L. S. Cabral. 2001. Characterization of the protein and the 
carbohydrate fractions and the respective degradation rates of Tifton 85 bermudagrass hay at different regrowth ages. Rev. Bras. Zootec. 30:589-595.

Schulze, E. D. 1993. Soil water deficits and atmosferic humidity as environmental signal in water déficits plants responses from cell to community (Eds. J. C. A. Smith and H. Griffi). Oxford Bios Scientific Publishers, Oxford, England p. 129-145.

Scudamore, K. A. and T. Livesey. 1998. Occurrence and significance of mycotoxins in forage crops and silage: A rewiew. J. Sci. Food Agric. 77:1-17.

Silva, D. J. and A. C. Queiroz. 2006. Food analysis: Chemical and biological methods. Ed UFV, Viçosa, Minas Gerais, Brazil, $235 \mathrm{p}$.

Taffarel, L. E., D. D. Castagnara, E. E. Mesquita, P. S. R. Oliveira, M. A. Neres, A. C. Radis, and P. V. Santos. 2011. Hay composition of Tifton 85 bermudagrass with nitrogen. In: Proceedings of the Brazilian Congress Animal Science. 23 Maceió, Brazil. pp. 1-3.
Taffarel, L. E., J. P. Ames, E. E. Mesquita, D. D. Castagnara, P. S. R. Oliveira1, and L. C. Souza. 2011. Chemical composition of Tifton 85 hay in two regrowth ages. In: Proceeding of the Annual Meeting of the Brazilian Society of Animal Science. 48, Belém, Brazil. p. 1-3.

Tilley, J. M. A. and R. A. Terry. 1963. A two-stage technique for the in vitro digestion of forage crops. J. Br. Grassland 18:104111.

Turner, J. E., W. K. Coblentz, D. A. Scarbrough, K. P. Coffey, D. W. Kellogg, L. J. McBeth, and R. T. Rhein. 2002. Changes in nutritive value of bermudagrass hay during storage. Agron. J. 94:109-117.

Van Soest, P. J. 1994. Nutritional Ecology of the Ruminant. Cornell University Press, Ithaca, NY, USA. p. 463.

Van Soest, P. J., J. B. Robertson, and B. A. Lewis. 1991. Methods for dietary fiber, neutral detergent fiber, and nonstarch polysaccharides in relation to animal nutrition. J. Dairy Sci. 74: 3583-3597.

Welz, B. and M. Sperling. 1999. Atomic Absortion Spectrometry. 3rd ed. Willey-VHC, Weinheim, Germany. 907 p. 